PNNL-13436

\title{
FUNCTIONS AND REQUIREMENTS FOR THE DST KNUCKLE REGION ULTRASONIC SCANNING SYSTEM
}

\author{
Pacific Northwest National Laboratory Document Number PNNL-13436
}

January 29, 2001

Task Funded Under TTP \# RL37C131

Prepared By

Allan F. Pardini

Todd J. Samuel
Pacific Northwest National Laboratory
Richland, Washington 99352

Prepared for the U.S. Department of Energy under Contract DE-AC06-76RLO 1930

This work is funded by the Office of Science and Technology within the Energy's Office of

Environmental Management under the Tanks Focus Area Program 
DISCLAIMER

This report was prepared as an account of work sponsored by an agency of the United States Government. Neither the United States Government nor any agency thereof, nor Battelle Memorial Institute, nor any of their employees, makes any warranty, express or implied, or assumes any legal liability or responsibility for the accuracy, completeness, or usefulness of any information, apparatus, product, or process disclosed, or represents that its use would not infringe privately owned rights. Reference herein to any specific commercial product, process, or service by trade name, trademark, manufacturer, or otherwise does not necessarily constitute or imply its endorsement, recommendation, or favoring by the United States Government or any agency thereof, or Battelle Memorial Institute. The views and opinions of authors expressed herein do not necessarily state or reflect those of the United States Government or any agency thereof.

\section{PACIFIC NORTHWEST NATIONAL LABORATORY \\ operated by \\ BATTELLE \\ for the \\ UNITED ST A TES DEPARTMENT OF ENERGY under Contract DE-AC06-76RLO1830}

Printed in the United States of America

@ This document was printed on recycled paper. 
PNNL-13436

APPROVALS A. F. Pardini Sensors and $_{\mathrm{NDE} \text { Measurements Group }}$

Pacific Northwest National Laboratory

C. E. Jensen

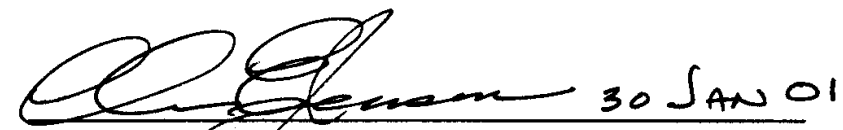

DST Maintenance and Reliabrility Engineering

$\mathrm{CH} 2 \mathrm{M}$ Hill Hanford Group 
PNNL-13436

\section{ABSTRACT}

This document defines the functions and requirements for an ultrasonic scanning system to provide an examination of the knuckle region of Hanford's double shell waste tanks. This document provides the basis for the ultrasonic concept selection, design, fabrication, and deployment methodology. 
PNNL-13436

\section{Table of Contents}

\begin{tabular}{|c|c|}
\hline 1.0 & INTRODUCTION \\
\hline 1.1 & 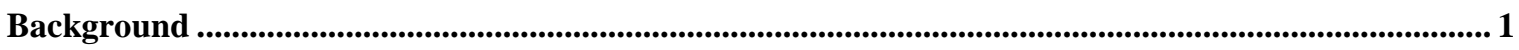 \\
\hline 1.2 & 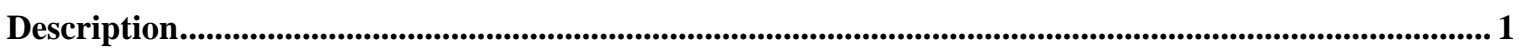 \\
\hline 1.3 & 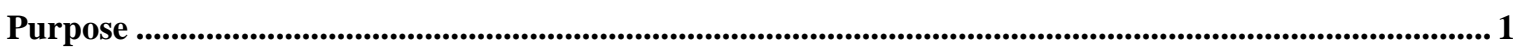 \\
\hline 1.4 & Scope \\
\hline 1.5 & finition of terms ................................................................... \\
\hline
\end{tabular}

2.0 GENERAL ASSUMPTIONS, FUNCTIONS, \& REQUIREMENTS .......................

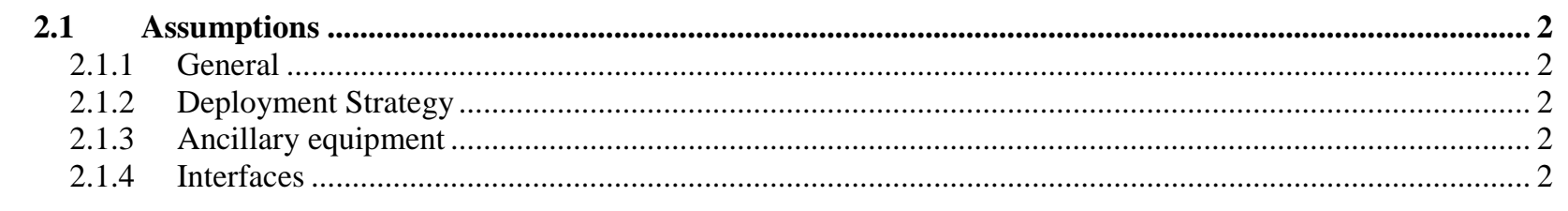

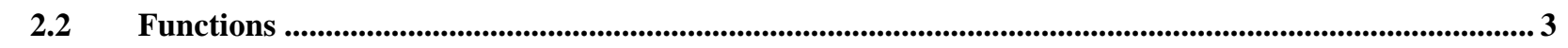

\begin{tabular}{|c|c|}
\hline 2.2 .1 & System Summary Function \\
\hline 2.2 .2 & 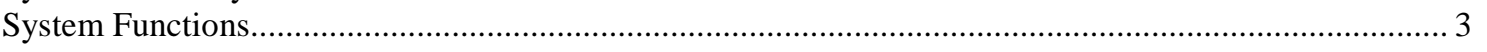 \\
\hline
\end{tabular}

\begin{tabular}{|l}
\hline 2.3 \\
\hline 2.3 .1
\end{tabular}




\subsection{SPECIFIC REQUIREMENTS FOR THE KNUCKLE REGION}

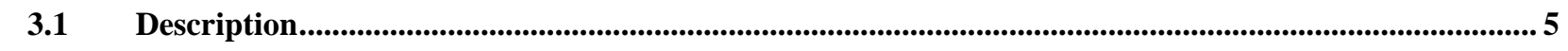

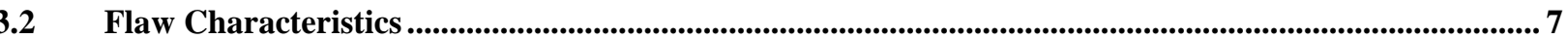

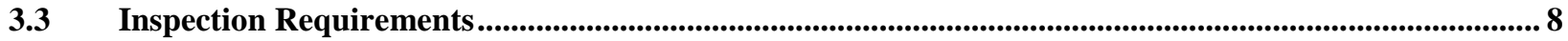

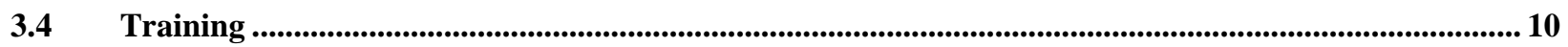

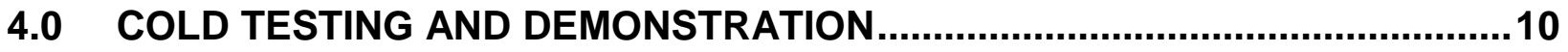

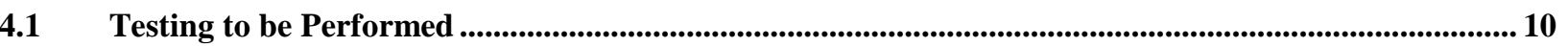

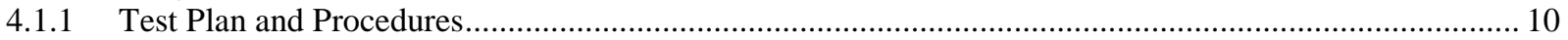

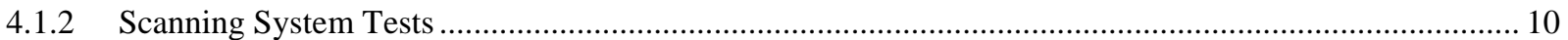

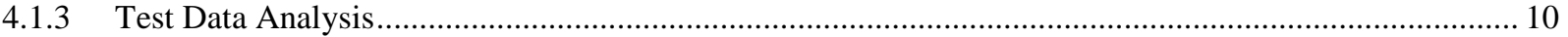

$4.2 \quad$ Test Success Criteria........................................................................................................................................................... 10

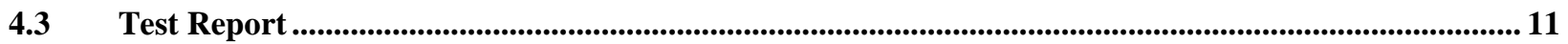

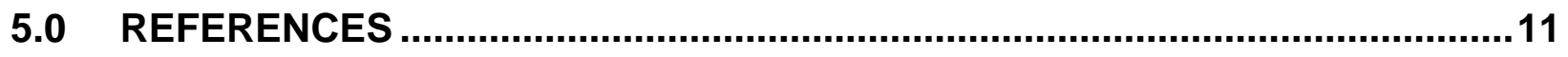

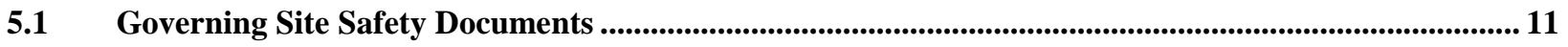

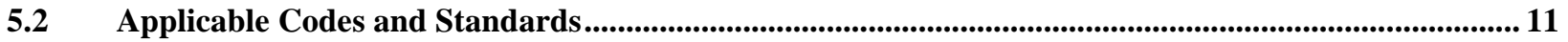

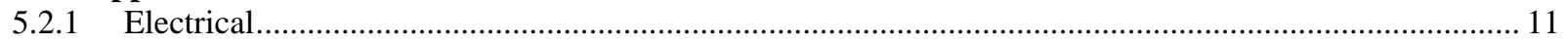

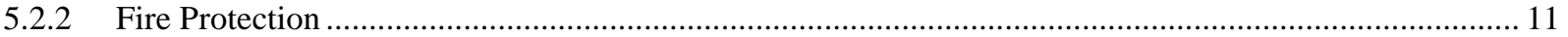

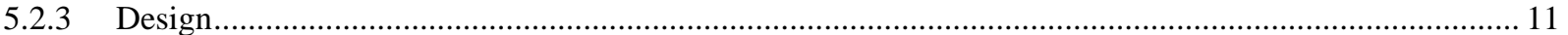

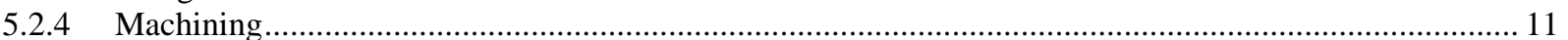

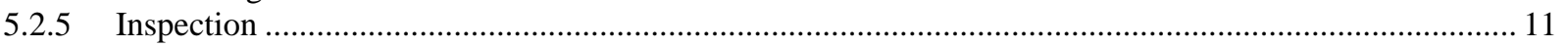

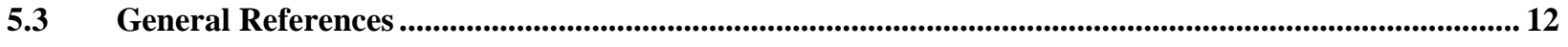


PNNL-13436

\section{ACRONYM LIST}

$\begin{array}{ll}\text { A } & \text { Amps } \\ \text { ALARA } & \text { As Low As Reasonably Achievable } \\ \text { DOE } & \text { Department of Energy } \\ \text { DST } & \text { Double Shell Waste Tank } \\ \text { NFPA } & \text { National Fire Protection Association } \\ \text { OSHA } & \text { Occupational Safety and Health Administration } \\ \text { PDT } & \text { Performance Demonstration Test } \\ \text { R/hr } & \text { Roentgen/hour } \\ \text { SST } & \text { Single-Shell Waste Tank } \\ \text { TWRS } & \text { Tank Waste Retrieval System } \\ \text { UPS } & \text { Uninterruptible Power Supply } \\ \text { VAC } & \text { Volts (Alternating Current) }\end{array}$




\subsection{INTRODUCTION}

\subsection{Background}

Since the 1940's, underground storage tanks have been used at the Hanford Site to store radioactive waste. The waste is a by-product of spent nuclear fuel processing for recovery of plutonium, uranium, and neptunium. There are 149 single-shell waste tanks (SST), and 28 double-shell waste tanks (DST). The tanks are located in the 200 East and 200 West areas of the Hanford Site.

The 28 DSTs are located in six tank farms and were constructed and put into service between 1968 and 1986. All are essentially of the same design and each tank has a storage capacity of about one million gallons.

To assure that the DSTs maintain their structural integrity, an inspection plan was developed and implemented (Pfluger 1994). The document describes the ultrasonic testing (UT) system, the qualification of the equipment and procedures, field inspection readiness, DST inspections, and post-inspection activities. The document also provides the basis for the flaw characterization requirements.

\subsection{Description}

This document defines the functions and requirements for an ultrasonic inspection system to provide an examination of the knuckle region of Hanford's double shell waste tanks. This document addresses examination requirements of DSTs only. Specifically, this document addresses the knuckle region with emphasis on pitting, wall thinning, and planar flaws (including stress corrosion cracks).

\subsection{Purpose}

The purpose of this document is to provide the basis for the ultrasonic inspection system concept selection, design, fabrication, and deployment methodology. This document is to serve as the technical basis for specifications for systems engineered, procured and deployed for ultrasonic examinations of the knuckle region of Hanford's double shell waste tanks.

\subsection{Scope}

This document provides the functions and requirements necessary to form the basis for the ultrasonic inspection system design. This document only pertains to the knuckle region of Hanford's double shell waste tanks and is based on requirements delineated in Hanford documents (Pfluger 1995, Jensen 1995, Fredenburg 2000, Jensen 2000, Silver 2000a, Silver 2000b) and other guidelines (Bandyopadhyay 1997).

\subsection{Definition of terms}

Function. A function is a description of the task that a system, subsystem or component must perform. It is not a description of the device in any manner, but may establish some of the parameters governing the overall geometry of the device. 
Requirement. A requirement is a mandatory factor that must be applied or incorporated into the design of the device performing the specified function. It is not a preference and uses the word shall.

Assumption. An assumption is the basis for a requirement that is taken to be true without necessarily having proof or demonstration. Changes in assumptions may have significant impacts on related requirements.

Shall/Must. The words "shall" or "must" denote a directive or requirement.

\subsection{GENERAL ASSUMPTIONS, FUNCTIONS, \& REQUIREMENTS}

\subsection{Assumptions}

\subsubsection{General}

The operation of the scanning equipment requires visual observation within the annulus region of the waste tank. The scanning equipment will be capable of being viewed from a remote camera located in strategic areas of the tank annulus.

\subsubsection{Deployment Strategy}

The ultrasonic scanning system will be deployed through existing 24-inch diameter risers. The scanning system will be capable of examining the entire knuckle region along the accessible circumference of the primary waste tank, as limited by vertical air pipes or other obstructions within the annulus.

\subsubsection{Ancillary equipment}

\subsubsection{Control Center}

Control of the ultrasonic scanning system will be housed in a control trailer located within 500 feet of the DST.

\subsubsection{Power}

Electrical power (110 VAC, $20 \mathrm{~A}$ (3) circuits) shall be available for the ultrasonic scanning system. An uninterruptible power supply (UPS) will be provided in the control trailer.

\subsubsection{Interfaces}

\subsubsection{Riser Access}

Deployment of the ultrasonic scanning system will be through available risers (at least 24 inches in diameter) with no other equipment in the riser. 


\subsubsection{Control Trailer}

Controls for the ultrasonic scanning system will be located in a control trailer setting near the DST. Power and control cables for the scanning system will be distributed on the waste tank top.

\subsection{Functions}

\subsubsection{System Summary Function}

The function of the ultrasonic scanning system is to provide an examination of the knuckle region of Hanford's DSTs to detect and characterize pitting, wall thinning, and planar flaws (including stress corrosion cracks).

\subsubsection{System Functions}

\subsubsection{Scanner}

The function of the scanner is to provide the mechanism for remotely placing ultrasonic transducers in contact with the knuckle region of the DST.

\subsubsection{Ultrasonic Control and Analysis}

The function of the ultrasonic control and analysis center is to provide the necessary computers and control hardware to operate the ultrasonic scanning system. An analysis computer will use proprietary software to perform analysis of the data collected by the scanning system.

\subsection{Requirements}

\subsubsection{Modular Design}

Each of the ultrasonic scanning system components shall incorporate modular design to facilitate replacement or servicing as needed.

\subsubsection{Interchangeability, Standard Components}

Equipment interchangeability shall be maximized to the extent practical. Standard commercially available parts, components and materials shall be used to the extent practical consistent with other functional requirements.

\subsubsection{Maintainability}

Scanning system components having a higher probability of failure (specifically the transducers) shall be mounted on fixtures that can easily be removed for servicing.

\subsubsection{Availability}

Equipment chosen for this project shall be commercial off-the-shelf as much as practical. 


\subsubsection{Redundancy}

Equipment redundancy shall be considered as a means to achieve reliability, availability and maintainability requirements.

\subsubsection{Efficiency}

Equipment shall be operated at rated voltage and as near peak efficiency as practical.

\subsubsection{Suitability}

The ultrasonic scanning system equipment shall be selected on the basis of "fit for purpose" and shall be assessed for reliability, availability, maintainability, diagnostic capability, schedule risk, versatility, and for life cycle cost.

\subsubsection{Safety}

Protection of the public, the system and site operators, the environment and the equipment supersede all other functions and requirements. A listing of applicable regulations and governing documents is provided in Section 5.0. The ultrasonic scanning system shall adhere to ALARA principles by limiting worker and environmental exposure to radiological materials, reducing the volume of secondary wastes, minimizing external contamination, and incorporating design features to ease maintenance of contaminated components. The safety classification for ultrasonic examination equipment for DSTs is General Services (GS), in accordance with Tank Farm Contractor procedures.

\subsubsection{Quality}

All equipment shall be fabricated in accordance with Tank Farm Contractor quality assurance requirements. The quality assurance classification for ultrasonic equipment for DSTs is Quality Level 3, in accordance with Tank Farm Contractor procedures.

\subsubsection{Lifting and Hoisting}

All hardware associated with hoisting and/or rigging for hoisting shall conform to DOE-HDBK1090-95, DOE Handbook "Hoisting and Rigging."

\subsubsection{Re-deployable}

The ultrasonic scanning system is to be re-deployable on multiple tank knuckles.

\subsubsection{Failure of Equipment}

The ultrasonic scanning system design shall not incorporate components whose failure could cause damage to the double shell waste tank or prevent removal of the system from the annulus.

\subsubsection{Environmental Conditions}

The ultrasonic scanning system must be designed to survive the following environmental conditions: 


\subsubsection{Waste Tank Annulus}

\subsection{Temperature}

Normal operation in annulus with temperatures up to 130 degrees Fahrenheit. Normal operation on primary tank wall with temperatures up to 200 degrees Fahrenheit.

\subsection{Radiation}

Normal operation with annulus radiation field of up to $640 \mathrm{R} / \mathrm{hr}$.

\subsection{Addition of Water}

The only couplant allowed within the waste tank annulus is water. The ultrasonic scanning system shall be designed to limit the water loss to the annulus to $<20$ gallons for the entire knuckle examination.

\subsubsection{Outside Conditions}

All equipment that is outside of the waste tank annulus shall be capable of operating in temperature extremes from -20 degrees Fahrenheit to 120 degrees Fahrenheit, periodic rain or snow, and frequent winds with gusts up to 80 miles per hour with blowing sand.

\subsubsection{Retrievable}

All ultrasonic scanning equipment deployed into the waste tank annulus must be retrievable under any circumstances for maintenance or repair purposes.

\subsubsection{Storage}

All ultrasonic scanning equipment shall be designed to allow for storage in unheated or uncooled containers with temperature ranges between 32 degrees Fahrenheit to 110 degrees Fahrenheit.

\subsection{SPECIFIC REQUIREMENTS FOR THE KNUCKLE REGION}

\subsection{Description}

The knuckle region of the DST that is to be inspected is located on the primary waste tank. The knuckle has a radius of 1 foot and is constructed of carbon steel. Figure 1 depicts a typical double shell tank configuration showing the primary tank, secondary tank, and knuckle region. 
PNNL-13436

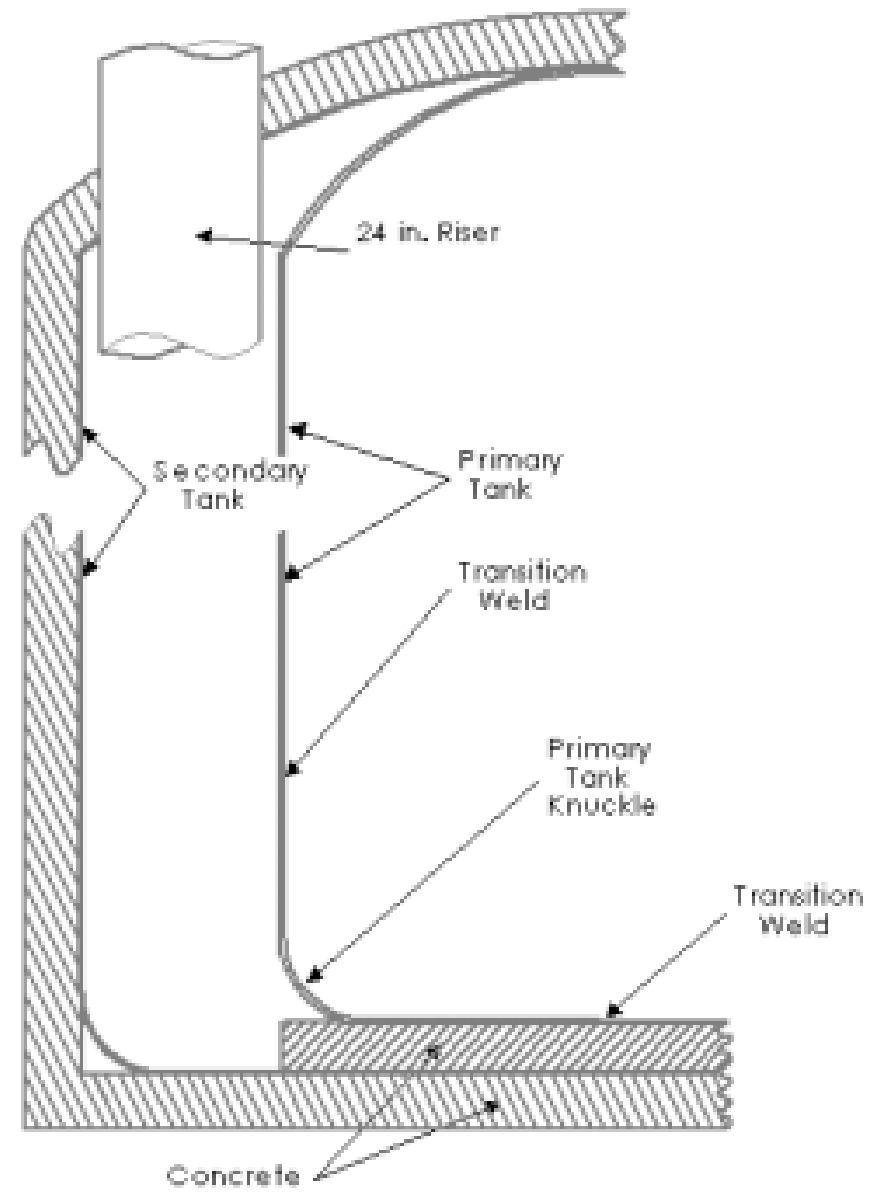

Figure 1 Annulus Region of Double-Shell Waste Tank 
During construction of Hanford's double-shell waste tanks, three different grades of steel were used along with two different plate thicknesses for the knuckle region. Table 1 provides a listing of steel grades used and knuckle thickness for various tanks (Pfluger 1994).

Table 1 Steel Grades and Thickness of Knuckle Region

\begin{tabular}{|l|l|l|l|l|}
\hline & $\begin{array}{l}\text { AN \& AW } \\
\text { Tanks }\end{array}$ & AP Tanks & SY Tanks & $\begin{array}{l}\text { AY \& AZ } \\
\text { Tanks }\end{array}$ \\
\hline ASTM Plate Specification & $\begin{array}{l}\text { A 537 } \\
\text { Class 1 }\end{array}$ & $\begin{array}{l}\text { A 537 } \\
\text { Class 1 }\end{array}$ & $\begin{array}{l}\text { A 516 } \\
\text { Grade 65 }\end{array}$ & $\begin{array}{l}\text { A 515 } \\
\text { Grade 60 }\end{array}$ \\
\hline Lower Knuckle Region Thickness (inch) & $7 / 8$ & $15 / 16$ & $7 / 8$ & $7 / 8$ \\
\hline
\end{tabular}

\subsection{Flaw Characteristics}

The flaw characteristics of interest are:

Pitting: Pitting that emanates from the inside surface of the tank shall be detected and sized. Pitting standards will be fabricated using hemispherical shapes to simulate real pits.

Planar Flaws: Planar flaws located in the knuckle region emanating from the inside surface of the tank shall be detected and sized. This region contains the highest stress point of the entire primary steel tank (Shurrab et al., 1991). Examinations shall concentrate on cracks that are caused by stress corrosion. Figure 2 provides a graphical example of a circumferential planar type stress corrosion crack that is of interest. Stress corrosion cracks oriented in the meridional direction are also of interest.

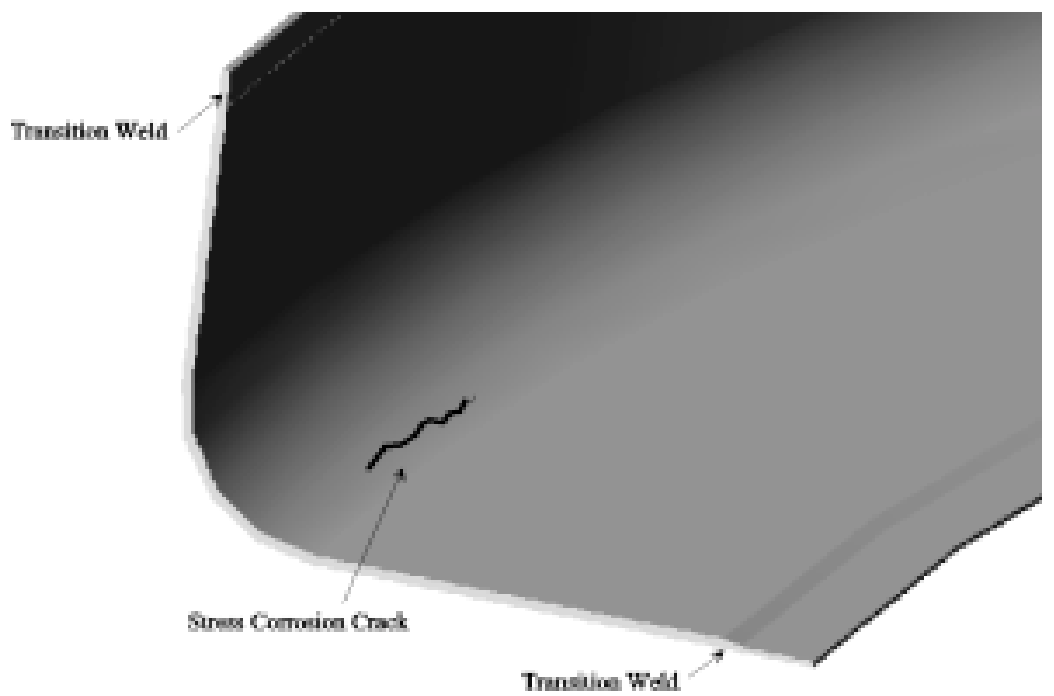

Figure 2 Planar Crack on Primary Tank Inside Diameter 


\subsection{Inspection Requirements}

The ultrasonic scanning system shall be capable of detecting wall thinning, pitting, and planar flaws located in the knuckle region of the primary tank. The knuckle region as shown in Figure 3 provides the inspection areas. The inspection area is the curved knuckle portion of the tank, generally bounded by the construction welds indicated in the figure. However the peak tensile stresses on the inside surface of the tank are believed to occur at the point where the tank knuckle comes into contact with the concrete insulating slab (see Figure 3). It is therefore desirable to have the capability to also examine a portion of the flat bottom immediately adjacent to the curved knuckle.

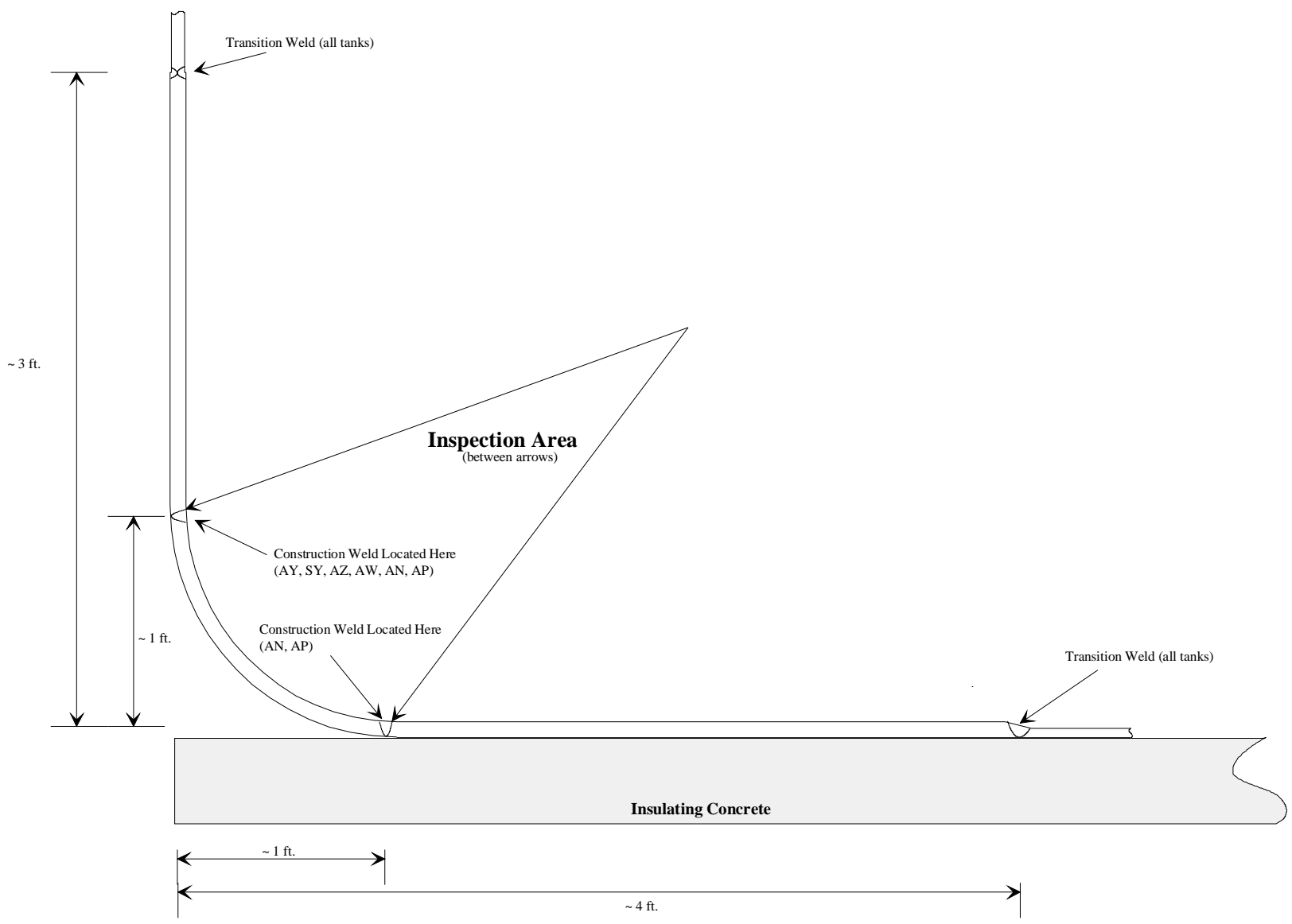

Figure 3 Inspection Parameters in Knuckle Region 
The ultrasonic scanning system shall be capable of detecting and sizing relevant indications according Tables 2 through 4 with the location requirement of Table 5 (Jensen 1999).

Wall thickness measurement shall be in accordance with Table 2.

Table 2 Wall Thickness Measurement Requirements

\begin{tabular}{|c|c|c|}
\hline Condition & $\begin{array}{c}\text { Minimum Dimension } \\
\text { To be Characterized }^{(1)}\end{array}$ & Accuracy \\
\hline Wall Thinning & $0.1 \mathrm{t}$ & \pm 0.020 inch \\
\hline
\end{tabular}

${ }^{1}$ Nominal tank wall thickness is t.

Pitting indications emanating from the inside surface shall be characterized in accordance with Table 3 .

Table 3 Pit Sizing Requirements

\begin{tabular}{|c|c|c|}
\hline Condition & $\begin{array}{c}\text { Minimum Dimension } \\
\text { To be Characterized }^{(1)}\end{array}$ & Accuracy \\
\hline Pitting & 0.25 deep $^{(2)}$ & \pm 0.050 inch \\
\hline
\end{tabular}

${ }^{1}$ Nominal tank wall thickness is $\mathrm{t}$.

${ }^{2}$ Pits are on the inside diameter of the knuckle region surface and have a hemispherical shape.

Circumferential cracks emanating from the inside surface shall be characterized in accordance with Table 4.

Table 4 Crack Sizing Requirements

\begin{tabular}{|c|c|c|}
\hline Condition & $\begin{array}{c}\text { Minimum Dimension } \\
\text { To be Characterized }\end{array}$ & Accuracy \\
\hline Cracks & 0.18 inch deep & \pm 0.10 inch \\
\hline
\end{tabular}

The ultrasonic scanning system shall be able to locate all reportable indications in accordance with Table 5. 
PNNL-13436

Table 5 Location Requirements

\begin{tabular}{|c|c|}
\hline Condition & Accuracy \\
\hline Indication Location & \pm 1.0 inch \\
\hline
\end{tabular}

\subsection{Training}

Ultrasonic system operators and analysts shall be qualified and certified to at least level II in accordance with the American Society for Nondestructive Testing (ASNT) recommended practice SNT-TC-1A. Additional training, specifically addressing advanced detection and sizing methods and analysis techniques shall be required. This additional training shall be at least 40 hours in duration.

\subsection{COLD TESTING AND DEMONSTRATION}

\subsection{Testing to be Performed}

Testing of the ultrasonic scanning system shall be performed to demonstrate proper operation and performance. It is assumed that the ultrasonic scanning system is set up and operational and all cabling connected in the configuration that will be used on the actual waste tanks.

\subsubsection{Test Plan and Procedures}

A test plan shall be written for testing of the ultrasonic scanning system. The test plan shall identify all necessary equipment and procedures for completing the test.

\subsubsection{Scanning System Tests}

The scanning system shall be deployed on a primary tank knuckle mock-up containing real or simulated defects. Operation of the scan, collection of a data set, and transfer of the data set to the analysis computer shall be demonstrated.

\subsubsection{Test Data Analysis}

Data shall be analyzed to demonstrate proper operation of the software and visualization equipment.

\subsection{Test Success Criteria}

The ability to remotely scan the knuckle region, transfer the data to the analysis computer, and provide defect analysis and interpretation will be the primary performance metric. Once the cold testing and demonstration is complete the ultrasonic scanning system will undergo a performance demonstration test (PDT). The PDT will be performed on a mockup of the knuckle region with known crack-like indications. Results of the PDT will be correlated with known data and an evaluation of performance will be made. 


\subsection{Test Report}

A test report shall be generated documenting the test configuration and test results.

\subsection{REFERENCES}

\subsection{Governing Site Safety Documents}

DOE-HDBK-1090-95, DOE Hoisting and Rigging Handbook, U.S. Department of Energy, Washington D.C., 1995

29 CFR Occupational Safety and Health Standards

\subsection{Applicable Codes and Standards}

\subsubsection{Electrical}

NFPA 780-1997 Lightning Protection Guide

ICS 1, Industrial Controls and Systems

ICS 6, Enclosures for Industrial Controls and Systems

\subsubsection{Fire Protection}

NFPA 70-93, National Electric Code, National Fire Protection Association, Batterymarch Park, Massachusetts, 1993

NFPA 101-91, Life Safety Code, National Fire Protection Association, Batterymarch Park, Massachusetts, 1991

\subsubsection{Design}

ANSI Y14.5M, Dimensioning and Tolerancing

AWS A2.4, Weld Symbols

\subsubsection{Machining}

ANSI B46.1, Surface Finishes

ANSI B1.1, Screw Threads

\subsubsection{Inspection}

SNT-TC-1A 1996, American Society for Nondestructive Testing, Columbus, Ohio 


\subsection{General References}

Bandyopadhyay, K. K., S. Bush, M. Kassir, B. Mather, P. Shewmon, M. Streicher, B. Thompson, D. van Rooyen, and J. Weeks. 1997. Guidelines for Development of Structural Integrity Programs for DOE High-Level Waste Storage Tanks, BNL-52527, Brookhaven National Laboratory, Upton, New York.

Fredenburg, E. A. 2000. Double-Shell Tank System Structural Integrity Program Plan, RPP-7340, Revision 0, CH2M Hill Hanford Group, Inc., Richland, Washington.

Jensen, C. E. 1995. Acceptance Criteria for Non-Destructive Examination of Double-Shell Tanks, WHC-SD-WM-AP-036, Revision 0, Westinghouse Hanford Company, Richland, Washington.

Jensen, C. E. 1999. Final Results of Double-Shell Tank 241-AN-107 Ultrasonic Inspection, HNF-3353 Rev. 1, Lockheed Martin Hanford Corporation, Richland, Washington.

Jensen, C. E. 2000. Engineering Task Plan for the Ultrasonic Inspection of Hanford DoubleShell Tanks - FY2001, RPP-6839 Revision 0, CH2M Hill Hanford Group, Inc., Richland, Washington.

Pfluger, D. C. 1994. Double-Shell Tank Ultrasonic Inspection Plan, WHC-SD- WM-AP-019, Revision 1, Westinghouse Hanford Company, Richland, Washington.

Pfluger, D. C. 1995. Double-Shell Tank Ultrasonic Inspection Performance Specification, WHC-S-4108, Revision 2, Westinghouse Hanford Company, Richland, Washington.

Shurrab, M. S., M. D. Thomson, J. R. Friley, M. R. Garnich, M. W. Rinker and F. A. Simonen. 1991. Parametric Studies to Support Inspection Criteria of the Hanford Site Double-Shell Waste Storage Tanks, WHC-EP-0508, Revision 0, Westinghouse Hanford Company, Richland, Washington.

Silver, D. 2000a. Failure to Comply with Major Milestone M-32 of the Tri-Party Agreement; Administrative Order No. U. S. Department of Energy 00NWPKW-1250, (Letter to R. French, U. S. Department of Energy, Office of River Protection; and K. Klein, U. S. Department of Energy, Richland Operations Office; dated June 13), State of Washington Department of Ecology, Olympia, Washington.

Silver, D. 2000b. Failure to Comply with Major Milestone M-32 of the Tri-Party Agreement; Administrative Order No. CH2M Hill Hanford Group 00NWPKW-1251, (Letter to M. P. Delozier, CH2M Hill Hanford Group; dated June 13), State of Washington Department of Ecology, Olympia, Washington. 


\section{Distribution}

No. of

Copies

OFFSITE

1 DOE/Office of Scientific and

Technical Information/Information Release

1 Tanks Focus Area Headquarters

Program Lead, c/o Kurt Gerdes

DOE Office of Science and Technology

19901 Germantown Road

1154Cloverleaf Building

Germantown, MD 20874-1290

$2 \quad$ Hanford Site

Chris E. Jensen R1-04

Ed A. Fredenburg R1-04

\section{ONSITE}

1 US DOE Operations Office

Ted P. Pietrok K8-50

6 Tanks Focus Area Technical Team

W. F. Bonner K9-14

10 Pacific Northwest National Laboratory

James M. Alzheimer K5-22

Susan S. Crawford K5-26

Aaron A. Diaz K5-26

Steven R. Doctor K5-26

Kevin L. Gervais K5-22

Allan F. Pardini (2) K5-26

Gerald J. Posakony K5-26

Todd J. Samuel K5-22

George J. Schuster K5-26 